\title{
PROPERTIES OF A PHTHALATE ESTERS HYDROLASE FROM ARTHROBACTER SP. ZJUTW AND COMPARISON OF ITS TRANSESTERIFICATION AND ESTER HYDROLYSIS ABILITY
}

\author{
QIU, L. - ZhANG, H. - YIN, X. - LIU, T. - WU, S.* \\ College of Biotechnology and Bioengineering, Zhejiang University of Technology, Hangzhou \\ 310032, China \\ *Corresponding author \\ e-mail:wujan28@zjut.edu.cn \\ (Received 22 $2^{\text {nd }}$ May 2019; accepted $28^{\text {th }}$ Aug 2019)
}

\begin{abstract}
Microbial degradation is suggested to be the principal mechanism for removing Phthalate esters (PAEs) from the environment. PAEs esterase is one of key enzymes in the degradation pathway. In this study, a phthalate esters hydrolase gene, pehA, that displays good alkali stability, is cloned from Arthrobacter sp. ZJUTW and characterized. The enzyme showed a monomeric structure with a molecular mass of approximately $26.17 \mathrm{kDa}$ and $\mathrm{pI}$ of 4.42 . Its optimal $\mathrm{pH}$ and temperature were $\mathrm{pH} 10.0$ and $50{ }^{\circ} \mathrm{C}$, respectively. The enzyme was stable in a $\mathrm{pH}$ ranging from 8.0 to 10.0. In addition, the ester hydrolysis and transesterification catalytic ability of the esterase were compared through high performance liquid chromatography (HPLC) and Gas Chromatography-Mass Spectrometer (GC-MS). When performing the ester hydrolysis function, PehA has the catalytic ability to hydrolyze two ester bonds at the same time. The kinetic parameters of transesterification and ester hydrolysis conditions showed that the catalytic efficiency of transesterification is significantly higher than that of ester hydrolysis, and PehA preferentially catalyzed transesterification with PAEs and methanol as a substrate. This is the first report on the comparison of transesterification and ester hydrolysis ability of the PAEs esterase.
\end{abstract}

Keywords: PehA, gene cloning, endocrine disrupting chemicals, degradation, purification

\section{Introduction}

Phthalate esters (PAEs) are important synthetic organic compounds used as plasticizers in the industrial production of plastics. However, PAEs have become dangerous pollutants in environmental samples in recent years as endocrine disrupting chemicals which influence the genitals. Among rats and adult men, researches have shown that phthalate exposure increased DNA damage in sperm, induced hepatocellular tumors and in some cases reproductive toxicity (Fatoki and Ogunfowokan, 1993; Wang et al., 2004). Some of the PAEs including dimethyl phthalate (DMP), di-n-butyl phthalate (DBP), and di-n-octyl phthalate (DOP) have been listed as priority pollutants by the China National Environmental Monitoring Center (Fenner et al., 2013) and the US Environmental Protection Agency (Xu et al., 2005).

Since the photolysis and chemical hydrolysis rates of phthalate esters are very slow, microbial degradation is suggested to be the principal mechanism for removing PAEs from the environment. In recent years, some microorganisms have been reported to be capable of PAE degradation, these include Gordonia sp. (Jin et al., 2012), Pseudomonas sp. (Wang et al., 2003), Arthrobacter sp. (Wang et al., 2012), Rhodococcus sp. (Jin et al., 2010), Camelimonas sp. (Chen et al., 2014), Pelotomaculum and Desulfotomaculum species (Qiu et al., 2004). Numerous studies have demonstrated the microbial biodegradation pathways of phthalate esters. The metabolism of phthalate esters is initiated in bacteria by their hydrolysis converting them into mono-phthalate esters, 
which are further degraded by ester-hydrolysis to phthalate (PA). PA is further metabolized in aerobic bacteria by two different dioxygenase-initiated pathways through the common intermediate, protocatechuate (3,4-dihydroxybenzoate). Protocatechuate is further degraded into organic acids through either ortho- or metacleavage pathway by ring cleavage enzymes, which eventually converted them into $\mathrm{CO}_{2}$ and $\mathrm{H}_{2} \mathrm{O}$ through Krebs cycle (Eaton, 2001; Stingley et al., 2004; Ren et al., 2018).

Hydrolysis of the ester bond is a common key initial step in the microbial degradation of PAEs. PAEs esterase is one of key enzymes in the degradation pathway. However, only a few enzymes involved in this reaction have been reported. These enzymes include dimethyl terephthalate (DMT) esterase from Fusarium sp. DMT-5-3 (Luo et al., 2012), two distinct PAE hydrolases in Micrococcus sp. YGJ1 (Akita et al., 2001; Maruyama et al., 2005), mono-2-ethylhexyl phthalate hydrolase from Gordonia sp. P8219 (Nishioka et al., 2006; Iwata et al., 2016), ester hydrolase PatE from Rhodococcus jostii RHA1 (Hara et al.,2010), DBP hydrolase CarEW from Bacillus sp. K91 (Ding et al.,2015), DBP hydrolase from Acinetobacter sp. M673 (Wu et al., 2013), and Esterase EstB and EstG from Sphingobium sp. SM42 (Whangsuk et al., 2015). The esterase can either cleave the ester bond by ester hydrolysis or transesterify with alcohols. Previous studies have only reported the ester hydrolysis catalytic ability of PAEs esterase, but not explored its transesterification ability. Due to the complex composition of pollutants in the environment, it is possible that both alcohols and PAEs exist simultaneously. It is necessary to explore the transesterification of microorganisms and their esterases.

The PAEs esterase play important roles in the decontamination of PAEs. Studying the catalytic mechanism and recombinant expression of PAEs esterase can help improve the efficiency of PAEs pollutants treatment. In this paper, we described a basophilic enzyme from Arthrobacter sp. ZJUTW isolated from sludge of the river of Hangzhou city. This enzyme displayed specific hydrolase activity toward PAEs. The experimental data from HPLC and GC-MS led us to compare the ester hydrolysis and transesterification catalytic ability of the esterase.

\section{Materials and methods}

\section{Strains and reagents}

Arthrobacter sp. ZJUTW was isolated from sludge in Shangtang River of Hangzhou City, using dibutyl phthalate as sole carbon and energy source. The strain was deposited at the China Center for Type Culture Collection (CCTCC) under the accession number CCTCC M2012246.

DMP, diethyl phthalate (DEP), DBP, di (2-ethylhexyl) phthalate (DEHP) were purchased from Sinopharm Chemical Reagent Co., Ltd, all were $>98 \%$ pure. HPLCgrade methanol was purchased from Tianjin Siyou Fine Chemicals Co., Ltd. (Tianjin, China). Nickel-NTA agarose and pET28a expression kit were purchased from Shanghai Sangon Biological Engineering Technology Co., Ltd. (Shanghai, China). Other chemicals were analytical-reagent grade, and were purchased locally.

\section{Genome sequencing and sequence analysis}

Genomic DNA of Arthrobacter sp. ZJUTW was extracted using a genomic DNA isolation kit by Dalian Takara Biomedical Technology Co., Ltd (Dalian, China). 
Genome sequencing was performed by Zhejiang Tianke Biological Technology Co., Ltd. (Zhejiang, China) using Illumina Hiseq 2000 Sequencing platform, and a partial genomic sequence was obtained. Oligonucleotide primers were synthesized by Shanghai Sangon Biological Engineering Technology and Services Co., Ltd. (Shanghai, China). The full-length salicylate esterase gene pehA was revealed based on the prediction of ORFs from the partial genomic sequence by the Glimmer 3.02 (http://www.cbcb.umd.edu/software/glimmer/). Putative functions were inferred using the Basic Local Alignment Search Tool (BLAST) (http://blast.ncbi.nlm.nih.gov/Blast.cgi). Protein similarity search and alignment were performed using the data from CLUSTAL W (Thompson et al., 1994). The signal sequence for peptide cleavage in the amino acid sequences of pehA was predicted using SignalP 4.0 (www.cbs.dtu.dk/services/Signal P) (Petersen et al., 2011). ESPript output was used to render the analysis of multiple sequence alignment (Gouet et al., 1999). The neighbor-joining method in the molecular evolutionary genetic analysis software package MEGA (version 6.0) was used to construct a phylogenetic tree. The theoretical molecular mass and isoelectric point of the deduced pehA protein sequence was calculated using the Compute $\mathrm{pI} / \mathrm{Mw}$ tool on the ExPASy proteomics server (available at http://ex pasy.org/tools/p itool.html).

\section{Expression and purification of recombinant PehA}

The pehA gene was amplified by primers P1 (forward): 5'CGCGGATCCATGGAGATCGTACTGGTGCA-3' and P1 (reverse): 5'CCCAAGCTTCCA GTCCTGTTAGGCAATGAC-3'. Initial activation of the Taq DNA polymerase was performed for $5 \mathrm{~min}$ at $94{ }^{\circ} \mathrm{C}$, followed by 32 cycles as follows: $94{ }^{\circ} \mathrm{C}$ for $45 \mathrm{~s}$, then $55^{\circ} \mathrm{C}$ for $45 \mathrm{~s}, 72^{\circ} \mathrm{C}$ for $90 \mathrm{~s}$, followed by a final extension at $72{ }^{\circ} \mathrm{C}$ for $10 \mathrm{~min}$. Then following the manufacturer's instructions, the expression of pehA gene was performed using the pET28a expression kit. The PCR product was ligated to the $p E T 28$ a vector and introduced into E. coli BL21 (DE3) cells. Positive colonies were picked and grown in Luria-Bertani (LB) at $37^{\circ} \mathrm{C}$ in the presence of $50 \mu \mathrm{g} / \mathrm{ml}$ of kanamycin to an OD600 of 0.6 . The culture was then induced with $1.0 \mathrm{mM}$ IPTG and grown at $22{ }^{\circ} \mathrm{C}$ with shaking at $180 \mathrm{rpm}$ for $18 \mathrm{~h}$. The cells were harvested, re- suspended in $20 \mathrm{mM}$ potassium phosphate buffer $(\mathrm{pH} 8.0)$, and disrupted by sonication. After centrifugation at $12,000 \times \mathrm{g}$ at $4{ }^{\circ} \mathrm{C}$ for $15 \mathrm{~min}$, the supernatant was collected and further purified by a $2 \mathrm{ml}$ volume of $\mathrm{NTA}-\mathrm{Ni}^{2+}$ agarose following the manufacturer's instructions. The following purification was then performed by size exclusion chromatography on a Q Sepharose XL 10/30 column (Amersham Bioscience) equilibrated with $20 \mathrm{mM}$ sodium phosphate buffer $(\mathrm{pH} 8.0)$ at a flow rate of $1.0 \mathrm{ml} \mathrm{min}$. The purified recombinant PehA was examined using sodium salt-polyacrylamide gel electrophoresis (SDS-PAGE). The protein concentration was quantified using the Bradford procedure with bovine serum albumin as a standard.

\section{Assay of enzyme activity}

Enzyme activity was quantified at $40^{\circ} \mathrm{C}$, with $120 \mathrm{uL}$ of $10 \mathrm{mM} \rho$-nitrophenyl butyrate ( $\rho$-NPC4) substrates, $1.68 \mathrm{ml}$ of $50 \mathrm{mM}$ phosphate buffer $(\mathrm{pH} 8.0$ ), and $200 \mu 1$ of the purified PehA. Blank reactions were performed with every measurement to subtract appropriate values for non-enzymatic hydrolysis of the substrate. The production of $\rho$-nitrophenol $(\rho-\mathrm{NP})$ was monitored in triplicate every minute for $5 \mathrm{~min}$ 
at $405 \mathrm{~nm}$. One unit of esterase activity was defined as the amount of enzyme that produced $1 \mu \mathrm{mol} \rho$-NP in 1 min under the assay conditions

\section{Properties of the PehA}

The effect of $\mathrm{pH}$ and temperature on enzyme activity and stability was measured on $\rho$-NPC4 ester substrates for relative activity, which was expressed as a percentage of the initial activity. The optimum $\mathrm{pH}$ was determined by measuring the activity at $40{ }^{\circ} \mathrm{C}$ over the $\mathrm{pH}$ region 3.0-11.0. The stability at different $\mathrm{pH}(5.0-10.0)$ was determined after incubating the enzyme for $30 \mathrm{~min}$ and by measuring the relative activity at $40{ }^{\circ} \mathrm{C}$ and $\mathrm{pH}$ 8.0. The optimum temperature was determined by assaying the enzyme activity at various temperatures $\left(30-70{ }^{\circ} \mathrm{C}\right)$ for $20 \mathrm{~min}$ in $0.02 \mathrm{~mol} / 1$ potassium phosphate buffer ( $\mathrm{pH}$ 8.0). The thermostability was determined by measuring the remaining activity at $30{ }^{\circ} \mathrm{C}$ and $\mathrm{pH} 8.0$, after incubation of the purified esterase between 30 and $70{ }^{\circ} \mathrm{C}$ and $\mathrm{pH}$ 8.0 for $30 \mathrm{~min}$.

The effect of different potential inhibitors or activators (metal ions and organic solvents) on the enzyme activity was also determined by measuring the relative activity using a standard assay with $\rho$-NPC4 as the substrate. The reaction system was $120 \mu \mathrm{L}$ of $10 \mathrm{mM} \rho$-NPC4 ester substrates, $1.68 \mathrm{ml}$ of $50 \mathrm{mM}$ phosphate buffer ( $\mathrm{pH} \mathrm{8.0),200 \mu l}$ of the purified PehA, and a final concentration of $1.0 \mathrm{mM}$ of different metal or a final concentration of $1.0 \%$ (volume to volume ratio) of organic solvent. The enzyme was preincubated at $40{ }^{\circ} \mathrm{C}$ for $5 \mathrm{~min}$. The remaining activity was assayed was described. The activity assayed in the absence of inhibitors or activators was defined as the control.

\section{Comparison of transesterification and ester hydrolysis ability}

For comparing the transesterification and ester hydrolysis ability of PehA, the enzyme kinetic constants were determined by measuring the initial rate of enzymic reaction for DBP, DEP and DMP, which were firstly dissolved in methanol and dimethyl sulfoxide (DMSO), respectively. Parametric identification of maximum velocity $\left(\mathrm{V}_{\max }\right)$ and Michaelis-Menten constants $\left(\mathrm{K}_{\mathrm{m}}\right)$ was used from the equation for initial reaction velocity. The recombinant PehA assays were performed in $50 \mathrm{mM}$ Tris$\mathrm{HCl}$ buffer ( $\mathrm{pH} 8.0$ ) with $10 \mathrm{mM}$ of DBP, DEP or DMP (firstly dissolved in methanol and DMSO, respectively) at $40{ }^{\circ} \mathrm{C}$ for $10 \mathrm{~min}$. The substrate amount was then determined by HPLC/MS analysis. The substrate-free assay system was also used as blank simultaneously. Kinetic values were calculated from nonlinear regression data analysis against various substrate concentrations.

\section{HPLC and GC-MS analytical methods}

The mixture of enzymatic degradation was extracted with equal volume dichloromethane, then the extract was evaporated, and the residue was dissolved in $1 \mathrm{ml}$ methanol. The amount of remaining substrate was determined by HPLC (Agilent 1260 series, USA) equipped with a Diamonsil-C18 column $(4.6 \mathrm{~mm} \times 250 \mathrm{~mm} \times 5 \mu \mathrm{m}$; Dikma Technologies Inc, China). A mixture of methanol and $\mathrm{H}_{2} \mathrm{O}$ (90:10 by volume)

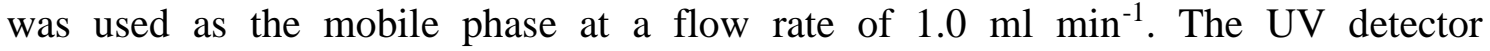
wavelength was $235 \mathrm{~nm}$ and the sampling quantity was $20 \mu \mathrm{l}$.

After collecting the HPLC peaks separately, enzymatic degradation products were identified using a Hewlett Packard 6890N gas chromatograph (Hewlett Packard, USA) equipped with an Agilent 5975C mass selective detector (Agilent, USA). The column 
used was a HP-5MS $(30 \mathrm{~m} \times 250 \mathrm{~m} \times 0.25 \mathrm{~m})$ capillary column. The temperature program consisted of $1 \mathrm{~min}$ hold at $60{ }^{\circ} \mathrm{C}$, an increase to $220{ }^{\circ} \mathrm{C}$ at $30{ }^{\circ} \mathrm{C} \mathrm{min}{ }^{-1}$, and $2 \mathrm{~min}$ hold, an increase to $250{ }^{\circ} \mathrm{C}$ at $5^{\circ} \mathrm{C} \mathrm{min}^{-1}$, and $2 \mathrm{~min}$ hold, an increase to $280{ }^{\circ} \mathrm{C}$ at $5{ }^{\circ} \mathrm{C} \mathrm{min}^{-1}$, and $3 \mathrm{~min}$ hold. The injection volume was $1 \mu \mathrm{l}$ and the carrier gas was helium $\left(1.0 \mathrm{ml} \mathrm{min}{ }^{-1}\right)$. The mass spectrometer was operated at an electron ionization energy of $70 \mathrm{eV}$. Instrumental library searches, comparison with available authentic compounds, and mass fragmentation pattern were used to identify the degradation products.

\section{Statistical analysis methodology}

Each treatment in the experiment was performed in triplicates. Software Origin 8.0 was used to draw the figures with error bars. Data are expressed as the mean \pm standard deviation (SD).

\section{Results and discussion}

\section{Sequence analysis of PehA}

A gene annotated as "salicylate esterase" with a 723-long ORF that encoded 240 amino acid proteins was found and we named it as pehA. No signal sequence was found. Sequence alignment revealed that amino acid sequence of pehA was $100 \%$ sequence identity to alpha/beta hydrolase from Gordonia QH-11 (Fig. 1), which was not reported about catalytic ability of PAEs. In addition, these sequences all contain the typical catalytic triad composed of Ser75-Glu194-His221 and the consensus motif (Gly-X-Ser$\mathrm{X}$-Gly) around the active-site serine (Fig. 2). Some PAEs esterases sequences were retrieved and compared with known representative esterases' sequences of eight families (Ren et al., 2018). The catalytic triad containing Ser, Glu (or Asp), and His was widely reported in families IV, V, and VII. Most enzymes in family V possess the typical $\alpha / \beta$-hydrolase fold with a catalytic triad (Arpigny and Jaeger, 1999), and existed basic amino acid ( $\mathrm{H}$ and $\mathrm{R}$ ) in GX1SX2GG motif, suggesting PehA belongs to the family $\mathrm{V}$. The sequence similarities and conservation of typical catalytic triads suggest that these enzymes may have a number of important common functions that were conserved during the course of evolution.

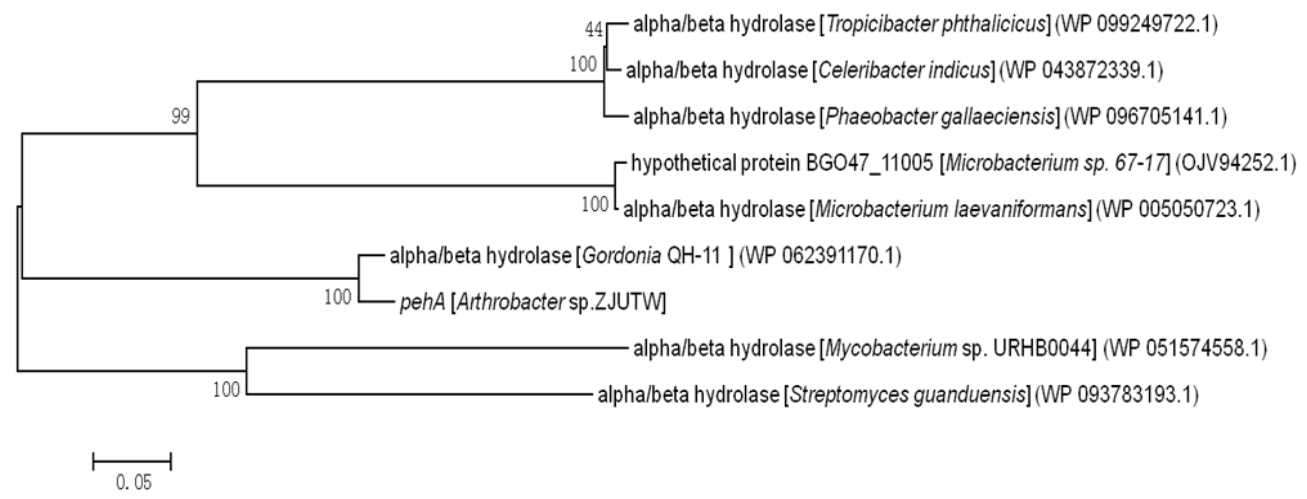

Figure 1. Neighbor-joining tree of esterases. Protein sequences were aligned using the built-in CLUSTAL W (default parameters), the tree was built using the neighbor-joining method with default parameters and 1000 bootstrap replications 



Figure 2. Protein sequences alignment between PehA and homologs from the carboxylesterase family. ESPript outputs obtained with the sequences from the SWISSPROPT databank and alignment with CLUSTAL W. Sequences are grouped according to similarity. WP_005054944.1 from alpha/beta hydrolase of Microbacterium; WP_024476681.1 from alpha/beta hydrolase of

Actinobacteria; WP_101851263.1 from alpha/beta hydrolase of Kocuria flava;

WP_062391170.1 from alpha/beta hydrolase of Gordonia phthalatica. A conserved pentapeptide (GXSXG), containing the serine residue of the catalytic triad, was framed by a dotted box. Symbols above blocks of sequences represent the secondary structure, springs represent helices, and arrows represent $\beta$-strands

\section{Enzyme cloning, overexpression and purification}

To investigate the biochemical properties of the enzyme, the pehA gene was expressed in the $p E T-28$ a vector as a $6 \times$ His tagged fusion protein and induced with $1 \mathrm{mM}$ IPTG or without IPTG at $20{ }^{\circ} \mathrm{C}$ for $18 \mathrm{~h}$. The crude enzyme extracted from recombinant $E$. coli $\mathrm{BL} 21$ cells was purified using $\mathrm{Ni}^{2+}$-NTA metal-chelating affinity chromatography and analyzed by SDS-PAGE. As shown in Figure 3 (lane 3), one band corresponded in size to the calculated molecular mass of PehA was detected 
$(26.17 \mathrm{kDa})$. The band was absent in the control lane from the E. coli BL21 cells induced without IPTG (Fig. 3, lane 1). The isoelectric point (pI) was 4.42.

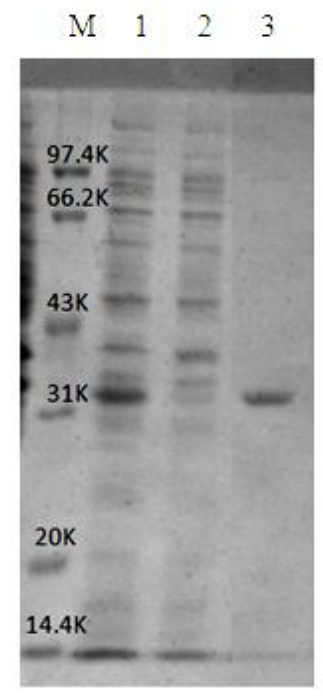

Figure 3. Analysis of the protein expressed in E. coli BL21 cells following purification on a $12 \%$ SDS- PAGE. Lane M, protein molecular marker; Lane 1, after induction with $1 \mathrm{mM}$ IPTG and grown at $20^{\circ} \mathrm{C}$ for $18 \mathrm{~h}$; Lane 2, before induction with IPTG; and Lane 3, purified recombinant PehA (molecular weight without histidine tag is $26.17 \mathrm{kDa}$ )

\section{Effect of pH and temperature on enzyme activity and stability}

The effect of $\mathrm{pH}$ on PehA activity was determined using $\rho$-NPC4 as the substrate at $40{ }^{\circ} \mathrm{C}$ with $\mathrm{pH}$ values ranging from 4.0 to 11.0 . Optimum activity was observed at $\mathrm{pH}$ 10.0, with approximately no activity at $\mathrm{pH} 4.0$ (Fig. 4A). The $\mathrm{pH}$ stability analysis revealed that the enzyme was very stable at $\mathrm{pH} 7.0-10.0$, retaining more than $70 \%$ of the original activity after pre-incubation at the given $\mathrm{pH}$ range for $60 \mathrm{~min}$. However, PehA only maintained $41 \%$ and $32 \%$ of its activity at $\mathrm{pH} 6.0$ and 11.0 , respectively, after incubation for $60 \mathrm{~min}$.

The effect of temperature on PehA activity was investigated using $\rho$-NPC4 as the substrate at $\mathrm{pH} 7.0$ with the temperature ranging from 30 to $70{ }^{\circ} \mathrm{C}$. Optimum activity was observed at $50{ }^{\circ} \mathrm{C}$. When the temperature rises above $50{ }^{\circ} \mathrm{C}$, the enzyme activity drops sharply. The temperature stability of PehA was examined by measuring its residual activity after incubating the purified enzyme for $0.5 \mathrm{~h}$ from 30 to $70{ }^{\circ} \mathrm{C}$. PehA retained approximately 95\%, 99\%, 86\% of its activity after incubation for $0.5 \mathrm{~h}$ at 30 , 40 and $50{ }^{\circ} \mathrm{C}$ respectively. However, the enzyme was unstable above $70{ }^{\circ} \mathrm{C}$, and retained approximately $33 \%$ of activity (Fig. 4 B).

\section{Effect of metal ions and organic solvents on enzyme activity}

The effect of different metal ions on PehA activity was examined by addition of each metal ion into the reaction mixture at a final concentration of $1.0 \mathrm{mM}$. The results are presented in Table $1 . \mathrm{Ni}^{2+}$, had a moderately inhibitory effect $(86.2 \%$ residual activity); $\mathrm{Mg}^{2+}, \mathrm{K}^{+}, \mathrm{Zn}^{2+}, \mathrm{Ba}^{2+}, \mathrm{Al}^{3+}$ and $\mathrm{Li}^{+}$had no apparent effect on enzyme activity; whereas $\mathrm{Co}^{2+}, \mathrm{Cu}^{2+}$ and $\mathrm{Mn}^{2+}$ activated PehA, and $\mathrm{Fe}^{3+}$ strongly activated PehA with residual activities of $163 \%$. 

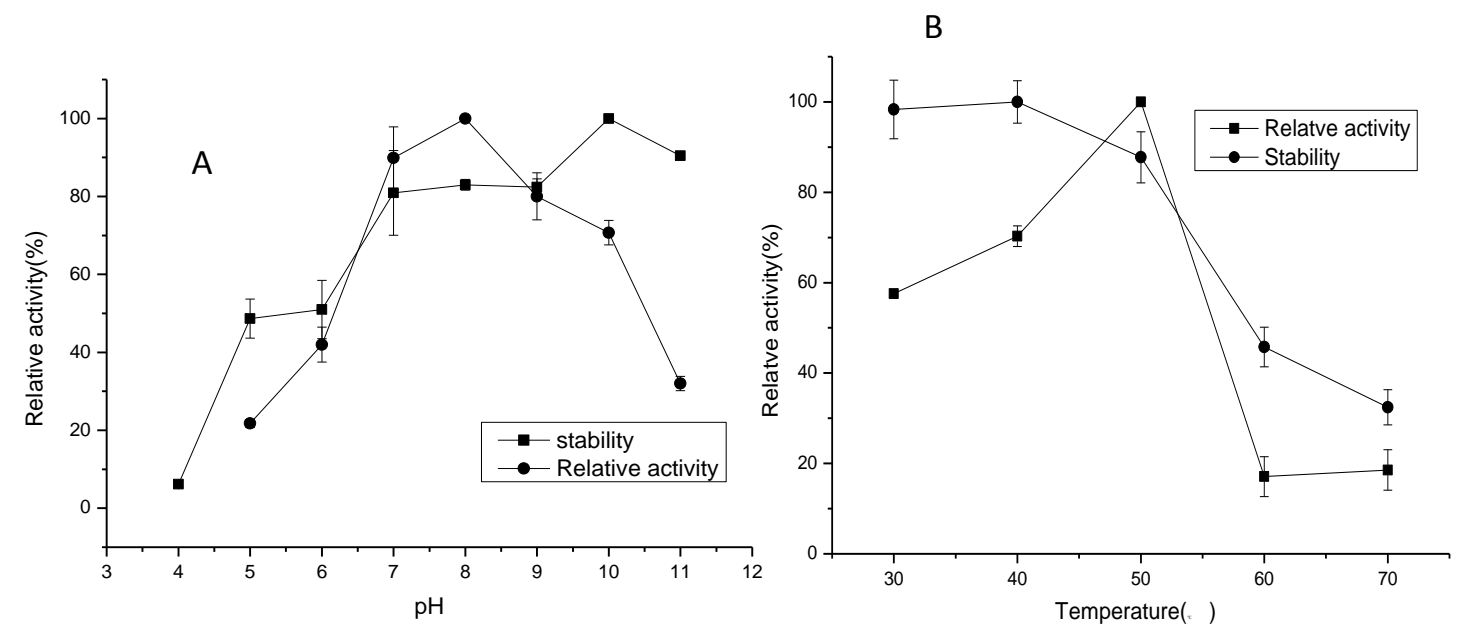

Figure 4. Effect of temperature and $p H$ on PehA activity and stability. Relative activity of purified PehA was determined at different $\mathrm{pH}(A)$ or temperatures $(B)$ using $\rho$-NP butyrate $(\rho$ NPC4) as the substrate at $405 \mathrm{~nm}$. Remaining enzyme activity was measured at $40{ }^{\circ} \mathrm{C}$ and $\mathrm{pH}$

8.0 after incubating purified PehA at different temperatures $(B)$ or $\mathrm{pH}$ for $60 \mathrm{~min}$

Table 1. Effect of various metal ions and organic solvents on enzyme activity

\begin{tabular}{c|c|c}
\hline Metal ions/organic solvents & Concentration & Relative activity (\%) \\
\hline control & $0 \mathrm{mmol} / \mathrm{L}$ & 100 \\
$\mathrm{Ni}^{2+}$ & $1 \mathrm{mmol} / \mathrm{L}$ & $86.2 \pm 3.78$ \\
$\mathrm{Mg}^{2+}$ & $1 \mathrm{mmol} / \mathrm{L}$ & $98.0 \pm 6.24$ \\
$\mathrm{Co}^{2+}$ & $1 \mathrm{mmol} / \mathrm{L}$ & $109.3 \pm 3.21$ \\
$\mathrm{Ba}^{2+}$ & $1 \mathrm{mmol} / \mathrm{L}$ & $105.4 \pm 2.61$ \\
$\mathrm{Zn}^{2+}$ & $1 \mathrm{mmol} / \mathrm{L}$ & $105.0 \pm 7.43$ \\
$\mathrm{Ca}^{2+}$ & $1 \mathrm{mmol} / \mathrm{L}$ & $112.3 \pm 6.37$ \\
$\mathrm{Cu}^{2+}$ & $1 \mathrm{mmol} / \mathrm{L}$ & $117.6 \pm 4.45$ \\
$\mathrm{Mn}^{2+}$ & $1 \mathrm{mmol} / \mathrm{L}$ & $123.0 \pm 3.54$ \\
$\mathrm{Fe}^{3+}$ & $1 \mathrm{mmol} / \mathrm{L}$ & $163.1 \pm 4.59$ \\
$\mathrm{~K}^{+}$ & $1 \mathrm{mmol} / \mathrm{L}$ & $107.3 \pm 2.15$ \\
$\mathrm{Al}^{3+}$ & $1 \mathrm{mmol} / \mathrm{L}$ & $101.2 \pm 2.07$ \\
$\mathrm{Methanol}^{3+}$ & $107.4 \pm 7.74$ \\
Ethanol & $1 \% \mathrm{~V} / \mathrm{V}$ & $109.9 \pm 8.21$ \\
$\mathrm{Acetone}^{2}$ & $1 \% \mathrm{~V} / \mathrm{V}$ & $105.5 \pm 1.88$ \\
DMSO & $1 \% \mathrm{~V} / \mathrm{V}$ & $97.4 \pm 0.81$ \\
Formaldehyde & $1 \% \mathrm{~V} / \mathrm{V}$ & $22.3 \pm 1.33$ \\
Acetonitrile & $1 \% \mathrm{~V} / \mathrm{V}$ & $93.8 \pm 21.97$ \\
Trichloromethane & $1 \% \mathrm{~V} / \mathrm{V}$ & $60.3 \pm 2.87$ \\
Tween 80 & $1 \% \mathrm{~V} / \mathrm{V}$ & $80.5 \pm 8.91$ \\
\hline
\end{tabular}

Organic solvents such as Formaldehyde (1\%) strongly inhibited PehA $(22.3 \%$ residual activity), and Trichloromethane (1\%) and Tween $80(1 \%)$ exhibited moderate 
inhibitory effects (approximately $60.3 \%$ and $80.5 \%$, respectively). Acetonitrile (1\%) and DMSO (1\%) had little inhibitory effect on the enzyme activity $(97.4 \%$ and $93.8 \%$ residual activities, respectively), whereas methanol (1\%), ethanol (1\%), and acetone (1\%) little activated PehA with residual activities of $107.4 \%, 109.9 \%$ and $105.5 \%$, respectively.

\section{Comparison of transesterification and ester hydrolysis ability of PehA}

Break of the ester bond is a common key initial step in the microbial degradation of phthalate esters. Esterase has two kinds of catalytic reactions involved transesterification and Ester hydrolysis to execute the Initial degradation step. To explore the catalytic ability for transesterification and Ester hydrolysis of PehA, The products of the reaction catalyzed were identified by HPLC and GC-MS. In the reaction system containing methanol, butyl methyl phthalate (BMP) was detected (Figs. 5A and $6 A, B)$, indicating that in this system, PehA exchanged a methyl group on methanol with butyl group of DBP through a transesterification reaction. In the reaction system containing no methanol (DBP dissolved in DMSO), PA was detected (Figs. 5B and 6C), and mono-butyl phthalate (MBP) was not detected, indicating that the esterase hydrolyzes two ester bonds simultaneously by ester hydrolysis to produce PA. However, in most of the previous reports, the initial step in the degradation of PAEs is that esterase hydrolyzes one ester bond to produce a monoester, then monoesterase hydrolyze another ester bond to form PA, suggesting that PehA has the catalytic ability to hydrolyze two ester bonds at the same time. Kcat/Km is one of the specificity constants of the enzyme, and can represent the specificity of the same enzyme for several substrates that compete with each other. The Kcat/Km ratio is a measure of the priority of different substrates, and the substrate with the larger Kcat/Km ratio is the preferred target for the enzyme. The kinetic parameters of different substrates were determined at $\mathrm{pH} 8.0$ and $40{ }^{\circ} \mathrm{C}$ using the purified recombinant PehA (Table 2). After comparing the ester hydrolysis and transesterification catalytic kinetic constants of several PAEs, the results showed that the ester hydrolysis catalytic activity of esterase was significantly stronger than that of transesterification. In Table 2, the Kcat $/ \mathrm{Km}$ values of DEP (containing methanol) and DEP (no methanol) as substrates are 41.02 and 0.47 , respectively, and that of DBP (containing methanol) and DBP (no methanol) are 8.95 and 0.213 , respectively, indicating that the catalytic efficiency of transesterification is significantly higher than that of ester hydrolysis in the presence of methanol, and PehA preferentially catalyzed transesterification with PAEs and methanol as a substrate. In addition, PehA exhibited strong catalytic ability for DBP and DEP, weak catalytic ability for DMP, and no catalytic ability for DEHP. This result suggested that PehA might have an ester chain length-dependence of PAEs. The kinetic parameters of some PAEs hydrolase are reported, the $\mathrm{Kcat} / \mathrm{Km}$ values of DBP as substrates are $0.109 \mathrm{~s}^{-1} \mu \mathrm{M}^{-1}$ (Ding et al., 2015), $0.07 \mathrm{~s}^{-1} \mu \mathrm{M}^{-1}$ (Jiao et al., 2013) and $10.11 \mathrm{~s}^{-1} \mu \mathrm{M}^{-1}$ (Wu et al., 2013), respectively, but all these data could only be measured at the condition of hydrolyzation. There is no report on the kinetic parameters of transesterification of these PAEs esterase. Some studies have reported that microorganisms can degrade PAEs through the ester conversion reaction process (Cartwright et al., 2000; Amir et al., 2005; Okamoto et al., 2011), but did not separate the esterases from these strains. To our knowledge, this is the first report on the comparison of transesterification and ester hydrolysis ability of PAEs esterase, and can help to further understand the degradation mechanism of PAEs by microbial. 


$$
-12946 \text { - }
$$
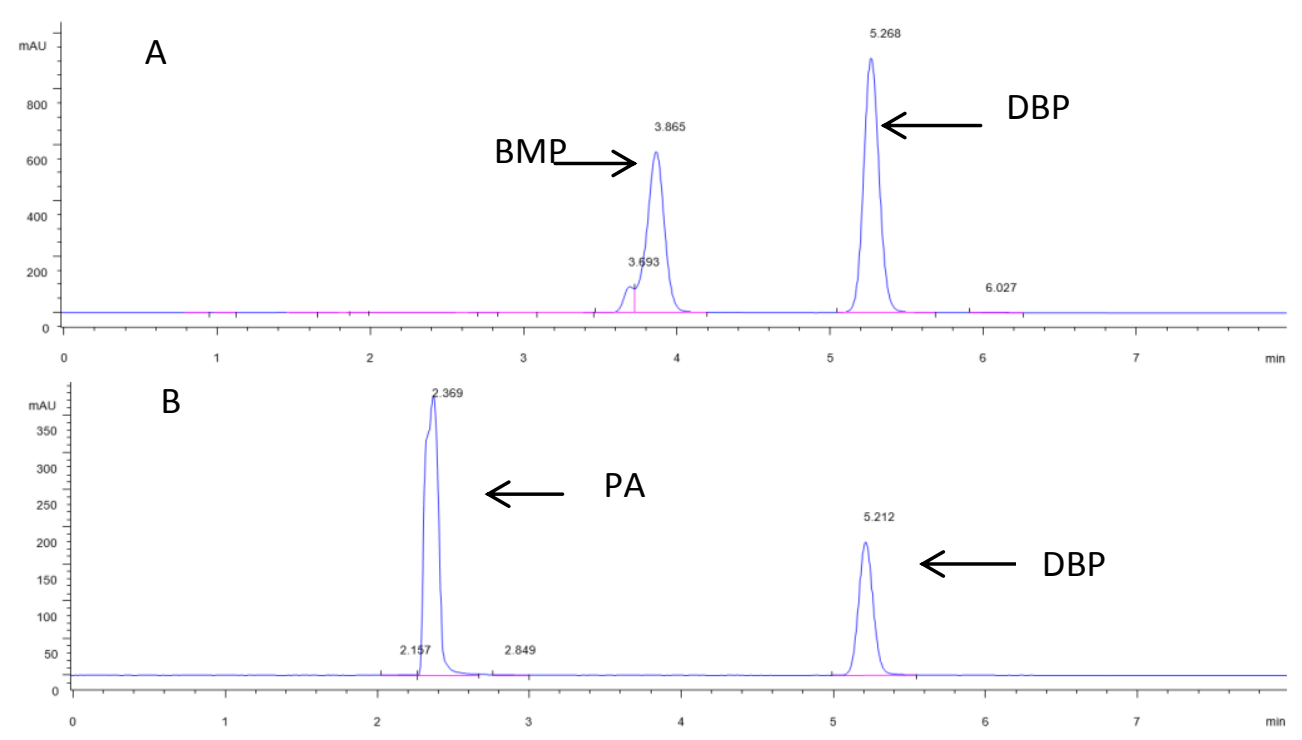

Figure 5. The results of HPLC analyses of enzymatic products. (A) The results of DBP dissolved in methanol as a substrate after incubation with PehA. (B) The results of DBP dissolved in DMSO as a substrate after incubation with PehA
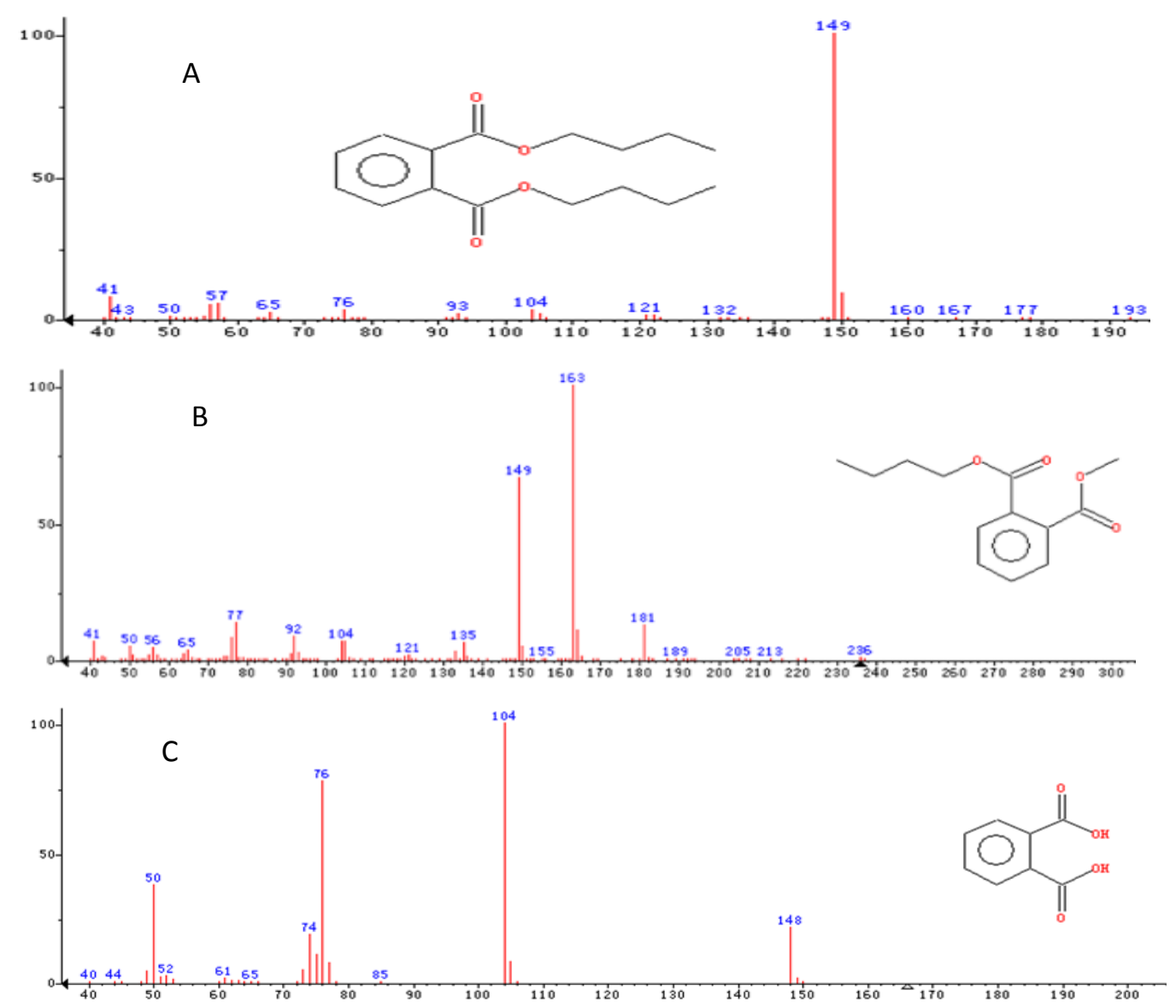

Figure 6. GC-MS analysis of products identified in the PehA catalyzed reaction. (A) Mass spectrometry of peak time of $5.212 \mathrm{~min}$ and $5.268 \mathrm{~min}$ by HPLC in Figure 5. (B) Mass spectrometry of peak time of 3.865 min by HPLC in Figure 5. (C) Mass spectrometry of peak time of 2.369 min by HPLC in Figure 5 
Table 2. Kinetic parameters of the recombinant PehA on different substrates at $p H 8.0$ and $40{ }^{\circ} \mathrm{C}$

\begin{tabular}{c|c|c|c|c}
\hline Substrate & $\begin{array}{c}\text { Vmax } \\
(\mathbf{m m o l} / \mathbf{m i n} \cdot \mathbf{m g})\end{array}$ & $\mathbf{K m}(\mathbf{m m o l} / \mathbf{l})$ & $\mathbf{K c a t}(/ \mathbf{s})$ & $\begin{array}{c}\mathbf{K c a t} / \mathbf{K m} \\
\mathbf{( I / / s} \cdot \mathbf{m m o l})\end{array}$ \\
\hline DEP (dissolved in methanol) & $41.17 \pm 1.32$ & $0.44 \pm 0.03$ & $17.9 \pm 1.44$ & 41.02 \\
DBP (dissolved in methanol) & $54.90 \pm 1.87$ & $2.67 \pm 0.02$ & $23.8 \pm 0.94$ & 8.95 \\
DMP (dissolved in methanol) & $0.239 \pm 0.01$ & $10.79 \pm 0.72$ & $0.104 \pm 0.01$ & 0.0096 \\
DEP (dissolved in DMSO) & $373.02 \pm 11.42$ & $347.6 \pm 9.35$ & $162.2 \pm 6.58$ & 0.470 \\
DBP (dissolved in DMSO) & $319.11 \pm 22.06$ & $472.5 \pm 13.18$ & $100.64 \pm 8.36$ & 0.213 \\
DMP (dissolved in DMSO) & $1.032 \pm 0.02$ & $1288 \pm 20.07$ & $3.56 \pm 0.4$ & 0.00276 \\
\hline
\end{tabular}

\section{Conclusions}

In this study, the pehA gene efficiently degraded several PAEs such as DBP, DEP and DMP, was cloned from Arthrobacter sp. ZJUTW and heterologously expressed in Escherichia coli BL21 using the pET28a expression system. The enzyme showed a monomeric structure with a molecular mass of approximately $26.17 \mathrm{kDa}$ and $\mathrm{pI}$ of 4.42 . The enzyme exhibited maximal activity at $\mathrm{pH} 10.0$ and $50{ }^{\circ} \mathrm{C}$, The enzyme was better stable within the $\mathrm{pH}$ range from 8.0 to 10.0. HPLC and GC-MS were employed to detect the catalytic ability of PehA. The results showed that this enzyme has two catalytic functions: transesterification and Ester hydrolysis. When performing the ester hydrolysis function, it has the catalytic ability to hydrolyze two ester bonds at the same time. Through comparing the kinetic parameters of transesterification and ester hydrolysis conditions, we found that the catalytic efficiency of transesterification is significantly higher than that of ester hydrolysis, and PehA preferentially catalyzed transesterification with PAEs and methanol as a substrate. The PAEs esterase play important roles in the decontamination of PAEs, the production of such recombinant enzyme can probably provide efficient biocatalysts at low costs for environmental protection purposes.

Acknowledgments. This study was supported by the Zhejiang Provincial Natural Science Foundation of China under Grant No. LY15C010002, for that the authors are grateful.

\section{REFERENCES}

[1] Akita, K., Naitou, C., Maruyama, K. (2001): Purification and characterization of an esterase from Micrococcus sp. YGJ1 hydrolyzing phthalate esters. - Bioscience Biotechnology and Biochemistry 65: 1680-1683.

[2] Amir, S., Hafidi, M., Merlina, G., Hamdi, H., Jouraiphy, A., El Gharous, M., Revel, J. C. (2005): Fate of phthalic acid esters during composting of both lagooning and activated sludges. - Process Biochemistry 40(6): 2183-2190.

[3] Arpigny, J. L., Jaeger, K. E. (1999): Bacterial lipolytic enzymes: classification and properties. - Biochemical Journal 343(1): 177-183.

[4] Cartwright, C. D., Owen, S. A., Thompson, I. P., Burns, R. G. (2000): Biodegradation of diethyl phthalate in soil by a novel pathway. - Fems Microbiology Letters 186(1): 27-34.

[5] Chen, X. P., Xu, S. S., Tan, T. F., Lee, S. T., Cheng, S. H., Lee, F., Xu, S., Ho, K. C. (2014): Toxicity and estrogenic endocrine disrupting activity of phthalates and their 
mixtures. - International Journal of Environmental Research and Public Health 11: 31563168.

[6] Ding, J. M., Wang, C. F., Xie, Z. R., Li, J. J., Yang, Y. J., Mu, Y. L., Tang, X. H., Xu, B., Zhou, J. P., Huang, Z. X. (2015): Properties of a Newly Identified Esterase from Bacillus sp. K91 and Its Novel Function in Diisobutyl Phthalate Degradation. - PLoS One 10: e0119216.

[7] Eaton, R. W. (2001): Plasmid-encoded phthalate catabolic pathway in Arthrobacter keyseri 12B. - Journal of Bacteriology 183: 3689-3703.

[8] Fatoki, O. S., Ogunfowokan, A. O. (1993): Determination of phthalate ester plasticizers in the aquatic environment of southwestern Nigeria. - Environment International 19: 619623.

[9] Fenner, K., Canonica, S., Wackett, L. P., Elsner, M. (2013): Evaluating pesticide degradation in the environment: blind spots and emerging opportunities. - Science 341: 752-758.

[10] Gouet, P., Courcelle, E., Stuart, D. I., Metoz, F. (1999): ESPript: analysis of multiple sequence alignments in Post-Script. - Bioinformatics 15: 305-308.

[11] Hara, H., Stewart, G. R., Mohn, W. W. (2010): Involvement of a novel ABC transporter and monoalkyl phthalate ester hydrolase in phthalate ester catabolism by Rhodococcus jostii RHA1. - Applied and Environmental Microbiology 76: 1516-1523.

[12] Iwata, M., Imaoka, T., Nishiyama, T., Fujii, T. (2016): Re-characterization of mono-2ethylhexyl phthalate hydrolase belonging to the serine hydrolase family. - Journal of Bioscience and Bioengineering 122: 140-145.

[13] Jiao, Y., Chen, X., Wang, X., Liao, X., Xiao, L., Miao, A., Wu, J., Yang, L. (2013): Identification and characterization of a cold-active phthalate esters hydrolase by screening a meta genomic library derived from biofilms of a wastewater treatment plant. - PLoS One 8(10): e75977.

[14] Jin, D., Bai, Z., Chang, D., Hoefel, D., Jin, B., Wang, P., Wei, D., Zhuang, G. (2012): Biodegradation of di-n-butyl phthalate by an isolated Gordonia sp. strain QH-11: Genetic identification and degradation kinetics. - Journal of Hazardous Materials 221-222: 80-85.

[15] Jin, D. C., Liang, R. X., Dai, Q. Y., Zhang, R. Y., Wu, X. L., Chao, W. L. (2010): Biodegradation of di-n-butyl phthalate by Rhodococcus sp. JDC-11 and molecular detection of 3,4-phthalate dioxygenase gene. - Journal of Microbiology and Biotechnology 20: 1440-1445.

[16] Luo, Z. H., Wu, Y. R., Chow, R. K. K., Luo, J. J., Gu, J. D., Vrijmoed, L. L. P. (2012): Purification and characterization of an intracellular esterase from a Fusarium species capable of degrading dimethyl terephthalate. - Process Biochemistry 47: 687-693.

[17] Maruyama, K., Akita, K., Naitou, C., Yoshida, M., Kitamura, T. (2005): Purification and characterization of an esterase hydrolyzing monoalkyl phthalates from Micrococcus sp. YGJ1. - Journal of Biochemistry 137: 27-32.

[18] Nishioka T., Iwata M., Imaoka T., Mutoh, M., Fujii, T. (2006): A mono-2-ethylhexyl phthalate hydrolase from a Gordonia sp. that is able to dissimilate di-2-ethylhexyl phthalate. - Applied and Environmental Microbiology 72: 2394-2399.

[19] Okamoto, Y., Toda, C., Ueda, K., Hashizume, K., Kojima, N. (2011): Transesterification in the microbial degradation of phthalate esters. - Journal of Health Science 57(3): 293299.

[20] Petersen, T. N., Brunak, S., von Heijne, G., Nielsen, H. (2011): SignalP 4.0: discriminating signal peptides from transmembrane regions. - Nature Methods 8: 785786.

[21] Qiu, Y. L., Sekiguchi, Y., Imachi, H., Kamagata, Y., Tseng, I. C., Cheng, S. S., Akiyoshi, O., Hideki, H. (2004): Identification and isolation of anaerobic, syntrophic phthalate isomer-degrading microbes from methanogenic sludges treating wastewater from terephthalate manufacturing. - Applied and Environmental Microbiology 70: 1617-1626. 
[22] Ren, L., Lin, Z., Liu, H., Hu, H. (2018): Bacteria-mediated phthalic acid esters degradation and related molecular mechanisms. - Applied Microbiology and Biotechnology 102: 1085-1096.

[23] Stingley, R. L., Brezna, B., Khan, A. A., Cerniglia, C. E. (2004): Novel organization of genes in a phthalate degradation operon of Mycobacterium vanbaalenii PYR-1. Microbiology 150: 2749-2761.

[24] Thompson, J. D., Higgins, D. G., Gibson, T. J. (1994): CLUSTAL W: improving the sensitivity of progressive multiple sequence alignment through sequence weighting, position-specific gap penalties and weight matrix choice. - Nucleic Acids Research 22: 4673-4680.

[25] Xu, X., Li, H., Gu, J. D. (2005): Biodegradation of an endocrine-disrupting chemical din-butyl phthalate ester by Pseudomonas fluorescens B-1. - International Biodeterioration \& Biodegradation 55: 9-15.

[26] Wang, Y., Fan, Y., Gu, J. D. (2003): Microbial degradation of the endocrine-disrupting chemicals phthalic acid and dimethyl phthalate ester under aerobic conditions. - Bulletin of Environmental Contamination and Toxicology 71: 810-818.

[27] Wang, Y., Miao, B., Hou, D., Wu, X., Peng, B. (2012): Biodegradation of di-n-butyl phthalate and expression of the 3,4-phthalate dioxygenase gene in Arthrobacter sp. ZH2 strain. - Process Biochemistry 47: 936-940.

[28] Wang, Y. Y., Fan, Y. Z., Gu, J. D. (2004): Dimetbyl phtbalate ester degradation by two planktonic and immobilized bacterial consortia. - International Biodeterioration \& Biodegradation 53: 93-101.

[29] Whangsuk, W., Sungkeeree, P., Nakasiri, M., Thiengmag, S., Mongkolsuk, S., Loprasert, S. (2015): Two endocrine disrupting dibutyl phthalate degrading esterases and their compensatory gene expression in Sphingobium sp. SM42. - International Biodeterioration \& Biodegradation 99: 45-54.

[30] Wu, J., Liao, X., Yu, F., Wei, Z., Yang, L. (2013): Cloning of a dibutyl phthalate hydrolase gene from Acinetobacter sp. Strain M673 and functional analysis of its expression product in Escherichia coli. - Applied Microbiology and Biotechnology 97: 2483-2491. 